\title{
Effects of carbon monoxide treatment before vacuum packaging on the physical parameters and consumer evaluations of raw beef
}

\author{
Anna SAKOWSKA ${ }^{1 *}$, Dominika GUZEK ${ }^{1}$, Agnieszka WIERZBICKA ${ }^{1}$
}

\begin{abstract}
This study examined the color changes of packaged beef due to the effects of carbon monoxide exposure before vacuum packing and storage time, as well as consumers' evaluations of that beef. In the experiment, 400 striploin steaks (M. longissimus dorsi) were vacuum packed or after 48 hours of exposure to different concentrations of $\mathrm{CO}(0.1 \%, 0.3 \%$, and $0.5 \%)$ vacuum packed. The color measurements and consumer evaluations were conducted after 7, 10,14,17, and 21 days of storage in the dark at $2 \pm 1{ }^{\circ} \mathrm{C}$. Consumers evaluated the color, surface discoloration, attractiveness, and their willingness to buy the meat. The results showed that regardless of storage time, the color parameters $\left(L^{*}, a^{*}, b^{*}, C^{*}\right)$ were significantly higher for the steaks vacuum packed after exposure to carbon monoxide in comparison to those packaged in a vacuum without the use of CO. Based on the consumer evaluations, the most attractive steaks were those that had been exposed to $0.3 \%$ and $0.5 \% \mathrm{CO}$, which were characterized by bright red or cherry-red colors. Consumers did not accept the appearance of steaks packaged without the carbon monoxide pretreatment. Exposing meat to $\mathrm{CO}$ before packaging allows to obtain the attractive color of vacuum packed beef.
\end{abstract}

Keywords: beef; carbon monoxide; color; vacuum packaging; consumer evaluation.

Practical Application: The application of low CO concentrations improves the color of vacuum-packed beef.

\section{Introduction}

The appearance of meat, especially its color, is one of the main factors in a consumer's purchasing decision. The color most desired by consumers is associated with freshness and is light red for beef (Mistura \& Colli, 2009; Zakrys-Waliwander et al., 2011; Olivera et al., 2013). Therefore, in addition to preserving freshness and quality, the packaging should also provide for the stability of the meat color (Carpenter et al., 2001; Mancini et al., 2009; Troy \& Kerry, 2010; Kameník et al., 2014; Zhou et al., 2014).

In industry, the most popular forms of packing are vacuum packaging and modified atmosphere packaging (MAP) (Behrends et al., 2003; Cayuela et al., 2004). In MAP, bright-red oxymyoglobin is formed on the beef surface due to the presence of oxygen. Consumers have accepted this meat color in the package for up to 14 days of storage. Unfortunately, MAP has several disadvantages, including the large size of the package, rapid oxidation of lipids, development of an off-flavor, and premature browning during cooking. In contrast, vacuum packaging, with its lack of oxygen, allows microbiological quality to be maintained longer and prevents or minimizes the lipid oxidation process. In addition, relative to MAP, vacuum packaging takes up much less space. But consumers do not accept the appearance of vacuum-packed meat, because the anaerobic conditions favor the reduction of myoglobin to dark-purple deoxymyoglobin. This is the primary reason why retail does not use this packaging method for small portions of fresh meat
(Mano et al., 2002; Cayuela et al., 2004; Marches et al., 2006; Cornforth \& Hunt, 2008; Šcetar et al., 2010).

Under anaerobic conditions, it is possible to obtain the meat color preferred by consumers by the use of low concentrations of carbon monoxide. This gas, in connection with myoglobin, forms a stable cherry-red carboxymyoglobin complex (El-Badawi et al., 1964). In the US, the use of $0.4 \%$ CO in modified atmosphere packaging was approved by the US FDA $(2002,2004)$ and has also been Generally Recognized as Safe (GRAS) (Jeong \& Claus, 2011). The European Scientific Committee on Food considered the use of $0.5 \%$ carbon monoxide during modified atmosphere packaging to be non-threatening to human health (EC, 2001).

There are currently no studies on how exposure to low-concentration carbon monoxide impacts the color of vacuum-packed bovine meat, particularly at $0.1 \%$ concentrations. Therefore, the aim of this study was to determine the effect of exposing meat (beef longissimus dorsi) to different concentrations of carbon monoxide $(0.1 \%, 0.3 \%$, and $0.5 \%)$ prior to vacuum packing with regard to its color stability and time in storage $\left(7,10,14,17\right.$, and 21 days) at $2 \pm 1{ }^{\circ} \mathrm{C}$. Our objective was also to determine consumers' opinions regarding the color and attractiveness of vacuum-packed meat that had been exposed to low carbon monoxide concentrations and stored for up to 21 days, and their willingness to buy it. 


\section{Material and methods}

\subsection{Sample preparation}

Research material was obtained from 10 animals ( 5 heifers and 5 bulls), a Holstein $\times$ Limousin crossbreed, aged 20-22 months. For the experiment 20 striploin muscles (M. longissimus dorsi) were cut three days postmortem. Twenty $2.54-\mathrm{cm}$ thick steaks were cut from each striploin muscle. These were then packaged under different packing conditions (Table 1) and stored at $2{ }^{\circ} \mathrm{C}$ for up to 21 days. All measurements were conducted after 7, 10, 14,17 , and 21 days of storage.

The following equipment and conditions were used for the MAP packaging: Semi-automatic tray-sealer (SEALPAC M3, Sealpac International, Harderwijk, Nederland), transparent trays $(18.5 \mathrm{~cm} \times 13.7 \mathrm{~cm} \times 5 \mathrm{~cm}$ ); an OTR (oxygen transmission rate) of $10 \mathrm{~cm}^{3} / \mathrm{m}^{2} / 24 \mathrm{~h}$ at $23{ }^{\circ} \mathrm{C} / 0 \% \mathrm{RH}$ (relative humidity); a WTR (water transmission rate) of $15 \mathrm{~g} / \mathrm{m}^{3} / 24 \mathrm{~h}$ at $38^{\circ} \mathrm{C} / 90 \%$ $\mathrm{RH}$; and barrier film with an OTR of $3 \mathrm{~cm}^{3} / \mathrm{m}^{2} / 24 \mathrm{~h}$ at $23^{\circ} \mathrm{C} / 0 \%$ $\mathrm{RH}$ and WTR of $8 \mathrm{~g} / \mathrm{m}^{3} / 24 \mathrm{~h}$ at $38{ }^{\circ} \mathrm{C} / 90 \% \mathrm{RH}$ (Despol, Poland). The gas mixtures were certified according to ISO 6141. A gas composition analysis (WITT gas analyzer, Type PA S/P, WITT-GASETECHNIK GmbH \& Co KG, Witten, Germany) was performed immediately after the modified atmosphere packaging, and the $\mathrm{O}_{2}$ concentration in the packages was always below $0.5 \%$. All of the steaks were vacuum-packed (EDESA VAC 10DT, Edesa Hostelera, Barcelona; vacuum degree - 95\%; $\mathrm{PA} / \mathrm{PE}$ transparent bags $-20 \mathrm{~cm} \times 25 \mathrm{~cm}$ and $90 \mu \mathrm{m}$ thickness, OTR $-50 \mathrm{~cm}^{3} / \mathrm{m}^{2} / 24 \mathrm{~h}$ at $23{ }^{\circ} \mathrm{C}$, WTR $-10 \mathrm{~g} / \mathrm{m}^{3} / 24 \mathrm{~h}$ at $38^{\circ} \mathrm{C}$ ) five days after slaughter, include those that were not exposed to carbon monoxide.

\section{2 pH measurements}

The $\mathrm{pH}$ of the samples was measured using a portable $\mathrm{pH}$-meter (Testo 205, Testo Ltd, Alton, Hampshire, UK) (calibrated in $\mathrm{pH}$ 4.01 and 7.00 buffers) with the probe inserted into the center of the meat samples. The measurements were made in triplicate.

\subsection{Color measurements}

Immediately after opening the package, the surface color of the raw steaks was evaluated using the CIELab color parameters $\mathrm{L}^{\star}$ (lightness), $\mathrm{a}^{\star}$ (redness), and $\mathrm{b}^{*}$ (yellowness) using a

Table 1. Packaging conditions.

\begin{tabular}{|c|c|c|}
\hline $\begin{array}{l}\text { Packaging } \\
\text { type }\end{array}$ & Conditions & Gas composition \\
\hline $0 \% \mathrm{CO}$ & vacuum & - \\
\hline $0.1 \% \mathrm{CO}$ & $\begin{array}{l}\text { vacuum after the previous } \\
48 \text { hours exposure to CO } \\
\text { in modified atmosphere } \\
\text { package }\end{array}$ & $\mathrm{CO} 0.1 \%, \mathrm{CO}_{2} 30 \%, \mathrm{~N}_{2} 69.9 \%$ \\
\hline $0.3 \% \mathrm{CO}$ & $\begin{array}{l}\text { vacuum after the previous } \\
48 \text { hours exposure to CO } \\
\text { in modified atmosphere } \\
\text { package }\end{array}$ & $\mathrm{CO} 0.3 \%, \mathrm{CO}_{2} 30 \%, \mathrm{~N}_{2} 69.7 \%$, \\
\hline $0.5 \% \mathrm{CO}$ & $\begin{array}{l}\text { vacuum after the previous } \\
48 \text { hours exposure to CO } \\
\text { in modified atmosphere } \\
\text { package }\end{array}$ & $\mathrm{CO} 0.5 \%, \mathrm{CO}_{2} 30 \%, \mathrm{~N}_{2} 69.5 \%$ \\
\hline
\end{tabular}

portable colorimeter (Minolta CR-400, Osaka, Japan) that had been standardized with a white standard plate. The following settings were used: 8 -mm measuring area, illuminant D65, and a $2^{\circ}$ standard observer angle. Ten readings were made for each sample. The CIE $L^{*}, a^{*}, b^{*}$ values were used to calculate the chroma $\left[\mathrm{C}^{\star}=\left(\mathrm{a}^{\star}+\mathrm{b}^{*}\right)^{1 / 2}\right]$ for each sample. The color differences between the vacuum-packed and carbon monoxide-treated samples due to the effects of the carbon monoxide were calculated for the various storage times using the following formula (Seydim et al., 2006):

$\Delta \mathrm{E}=\left[\left(\mathrm{L}^{*}-\mathrm{L}^{*}{ }_{\mathrm{VAC}}\right)^{2}+\left(\mathrm{a}^{*}-\mathrm{a}^{*}{ }_{\mathrm{VAC}}\right)^{2}+\left(\mathrm{b}^{*}-\mathrm{b}^{*}{ }_{\mathrm{VAC}}\right)^{2}\right]^{1 / 2}$,

where $\mathrm{L}_{\mathrm{VAC}}^{*} \mathrm{a}_{\mathrm{VAC}}^{*}$, and $\mathrm{b}_{\mathrm{VAC}}^{*}$ are the color parameter values of the vacuum-packed meat and $\mathrm{L}^{*}, \mathrm{a}^{*}$, and $\mathrm{b}^{*}$ are the color parameter values of the carbon monoxide-treated meat.

\subsection{Visual color evaluation}

The consumer test was attended by 150 people, and 15 panelists evaluated each steak. Images of the steaks were used for this consumer evaluation. This made it possible to avoid the impact of color changes due to blooming during the consumer assessment. The photographs were made immediately after opening the package using a Micropublisher 5.0 real-time viewing camera (QImaging, Surrey, BC, Canada) and Dulux L 36W/954 fluorescent lamps (Osram, München, Germany). Two hundred (4 package treatments $\times 5$ storage times $\times 10$ animals) images of the beef steaks were made. The consumers were asked to evaluate the meat color, surface discoloration, attractiveness, and their willingness to buy the meat using the following point scales:

- Color evaluated from 1 to 6 , where $1=$ pinkish red, 2 = bright red, $3=$ cherry red, $4=$ dark red/purple, $5=$ reddish $\tan /$ reddish brown, and $6=\tan /$ brown/gray (Hunt et al., 2004; De Santos et al., 2007; Suman et al., 2009; Rogers et al., 2014, with modifications)

- Surface discoloration evaluated from 1 to 5 , where discoloration was rated as 1 , not visible; 2 , slight (up to $10 \%$ ); 3 , small (11-20\%); 4, moderate (21-60\%); or 5, severe (61-100\%) (Martínez et al., 2005; Rogers et al., 2014)

- Attractiveness evaluated from 1 to 5 , where 1 = very unattractive, 2 = unattractive, 3 = moderately attractive, $4=$ attractive, and $5=$ very attractive (Carpenter et al., 2001, with modifications)

- Willingness to buy evaluated from 1 to 5 , where $1=$ definitely not buy, 2 = prefer not to buy, 3 = perhaps buy, $4=$ buy, and 5 = definitely buy (Carpenter et al., 2001; Rogers et al., 2014, with modifications).

\subsection{Statistical analysis}

The impact of the packaging and storage time on the physical parameters and consumer evaluation was determined using a two-way analysis of variance. Tests were conducted separately for each animal sex at significance levels of $0.05,0.01$, and 0.001 . The relationships between the variables were determined by Pearson correlations. The Pearson-correlation coefficient ( $r$ ) was calculated at a significance level of $\mathrm{p}<0.05$. All statistical analyses were performed using Statistica 10 (StatSoft, Tulsa, OK, USA). 


\section{Results and discussion}

\section{$3.1 p H$}

The results of the $\mathrm{pH}$ determination indicated that there was no significant effect of the animal's sex on the $\mathrm{pH}$ value ( $p>0.05$; Table 2). The general effects of storage time on the $\mathrm{pH}$ values were observed for both sexes, with a slow decrease in $\mathrm{pH}$ during storage being noted. Sakala et al. (2002) also reported a $\mathrm{pH}$ decrease for vacuum-packed beef, from $\mathrm{pH} 5.62$ to $\mathrm{pH}$ 5.12. These authors attributed the changes to the metabolism of lactic acid bacteria, which produce lactic acid. Kameník et al. (2014) and Hur et al. (2013) have respectively reported that the $\mathrm{pH}$ of stored vacuum-packed meat was stable for 21 and 35 days. These authors also observed a decrease in the $\mathrm{pH}$ of meat packed in a modified atmosphere, which was explained by the absorption of $\mathrm{CO}_{2}$. The decrease in $\mathrm{pH}$ of the meat in our study could have been caused by both the activity of lactic acid bacteria and $\mathrm{CO}_{2}$ absorption (packing with exposure to carbon monoxide). Another reason for the decline in $\mathrm{pH}$ could be an intracellular $\mathrm{pH}$ decrease due to postmortem anaerobic glycolysis (Laville et al., 2009).

\subsection{Color parameters}

The packing method, storage time, and their interactions significantly affected all of the measured color parameters (Table 2). The brightness ( $\mathrm{L}^{*}$ ) of the steaks was higher for those exposed to carbon monoxide than it was for those that were vacuum packed. This parameter also increased with exposure to higher concentrations of carbon monoxide before packaging. A general increase in the brightness of the steaks during storage time was also observed. These results are in agreement with those of Mancini et al. (2009), who reported an increase in the brightness of beef longissimus dorsi and psoas major steaks packaged in a vacuum and $0.4 \%$ CO MAP stored from 5 to 9 days. Kameník et al. (2014) similarly reported an increase in the $L^{*}$ value for a vacuum-packaged beef, from 33.6 (day 7) to 36.5 (day 35 ).

The use of carbon monoxide before vacuum packaging causing a significant increase in the redness of the examined steaks ( $p<0.001$; Table 2), with higher concentrations of carbon monoxide redness of the steaks increased. The differences in the $\mathrm{a}^{*}$ values of meat packaged after exposure to $0.1 \% \mathrm{CO}$ and $0.3 \%$ $\mathrm{CO}$ were noticeable after 14 days of storage. In addition, there was a significant decrease in the steaks' redness $\left(\mathrm{a}^{\star}\right)$ over time in storage ( $\mathrm{p}$ 0.001). Jayasingh et al. (2001) have also studied the effects of exposing meat to carbon monoxide before vacuum packing ( $5 \% \mathrm{CO}$ for $24 \mathrm{~h}$ and $100 \% \mathrm{CO}$ for $1 \mathrm{~h}$ ), and they reported an increase in the beef's redness with increasing concentrations of carbon monoxide exposure and a decrease in redness over time. Similarly Luño et al. (2000) noted this increase in the $\mathrm{a}^{*}$ values with increasing concentrations of carbon monoxide (from 0.1 to $1 \%$ ) in MAP. In another experiment, the use of $0.4 \%$ carbon monoxide in MAP had a positive effect - increasing the meat's redness compared to vacuum-packaged meat (Jeong \& Claus, 2011). The high $a^{*}$ values for the steak surfaces in that packaging were maintained for 21 storage days. The increase in redness of meat packaged with carbon monoxide results from the formation of light red carboxymyoglobin on its surface.
In our study, there was also a significant increase in the $\mathrm{C}^{\star}$ parameter with increasing concentrations of carbon monoxide $(0-0.5 \% ; \mathrm{p}<0.001)$. The chroma values changed during storage (Table 2), which agrees with the results of a report by Jeong \& Claus (2010). In their experiment, steaks packaged in a modified atmosphere with $0.4 \%$ carbon monoxide had higher $C^{*}$ values than did PVC-overwrapped steaks. The authors also observed an increase for this parameter over time during storage.

As previously mentioned, a major factor in the evaluation of meat is its appearance, in particular, its color. The $\Delta \mathrm{E}$ was calculated to quantify the changes in color due to the use of carbon monoxide prior to vacuum packaging. This parameter was used to determine the difference in color between meat packaged in a traditional vacuum and meat packaged in a vacuum after exposure to carbon monoxide. The following scale for the $\Delta \mathrm{E}$ values was used: $0-0.5$, not noticeable; $0.5-1.5$, slightly noticeable; $1.5-3.0$, noticeable; $3.0-6.0$, very visible; and $>6.0$ (extremely visible) (Cserhalmi et al., 2006).

The $\Delta \mathrm{E}$ values are shown in Figure 1 and Figure 2. The sex of the animal, the storage time, and the type of packaging significantly influenced the value of this parameter $(\mathrm{p}<0.05)$. The biggest differences in color were observed after 7 days of

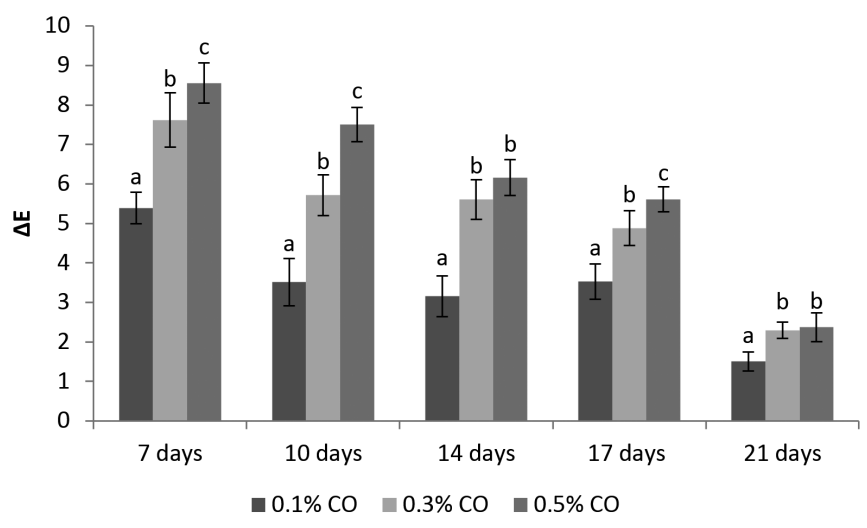

Figure 1. The color difference between the samples packaged under vacuum and using carbon monoxide in heifers longissimus dorsi muscle. Different letters $(\mathrm{a}-\mathrm{c})$ within a same storage day differ significantly $(\mathrm{p}<0.05)$.

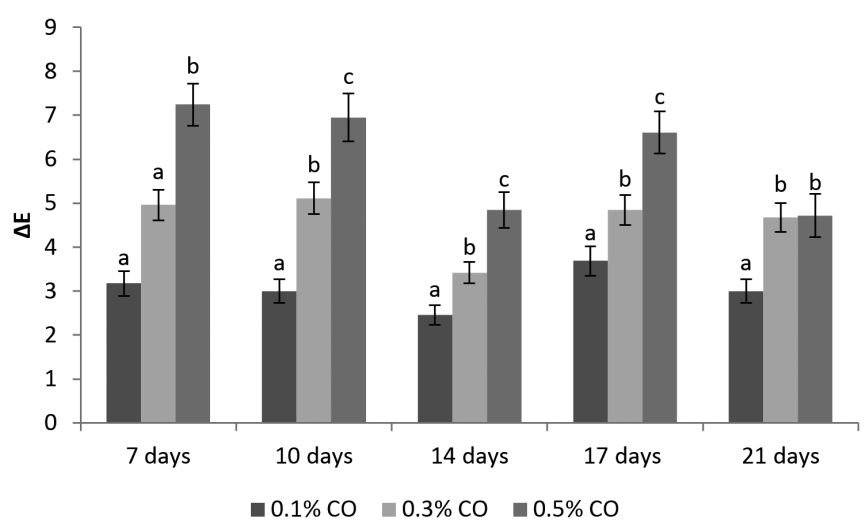

Figure 2. The color difference between the samples packaged under vacuum and using carbon monoxide in bulls longissimus dorsi muscle. Different letters $(a-c)$ within a same storage day differ significantly $(\mathrm{p}<0.05)$. 


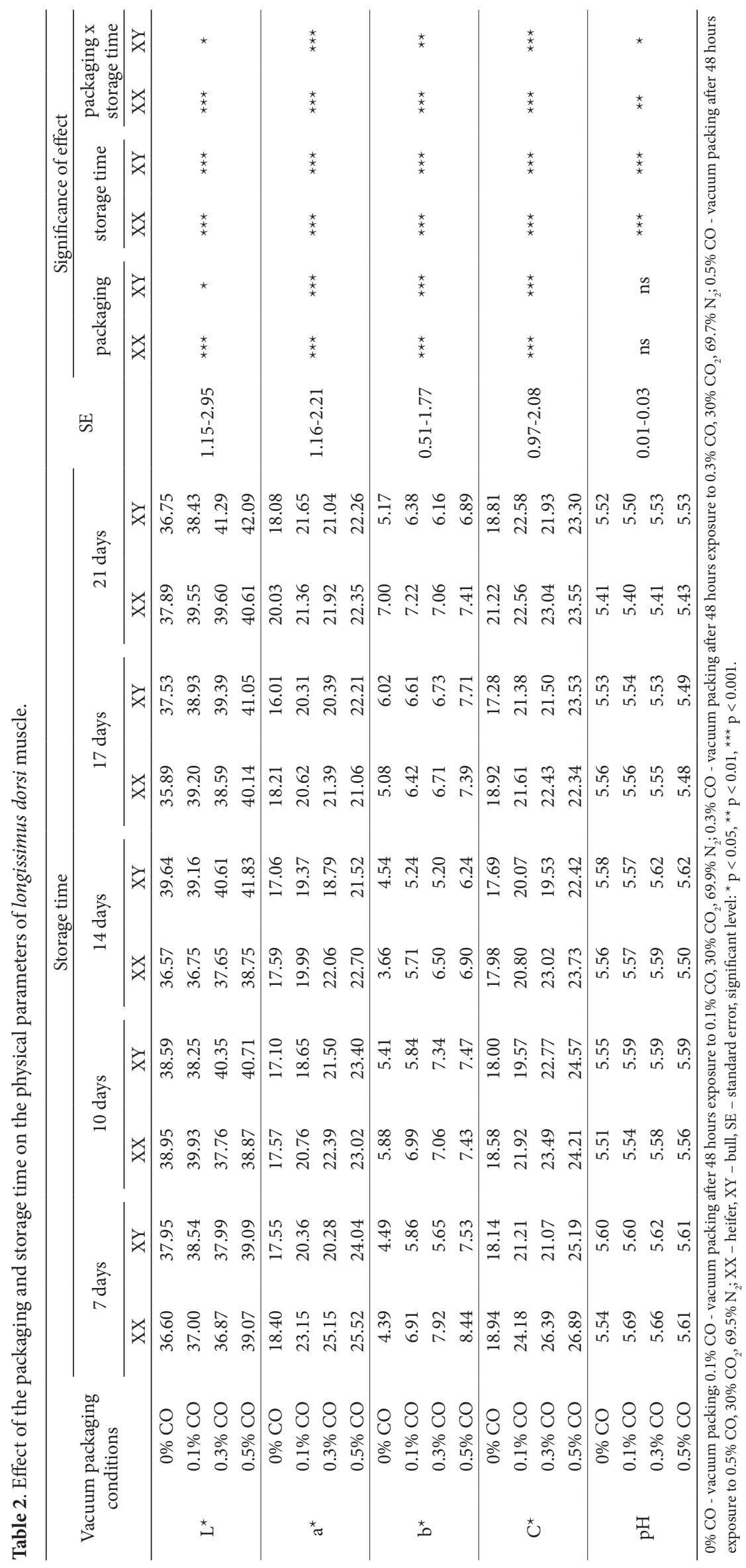


storage, being either very or extremely visible according to the assessment scale described above. The difference in color decreased significantly over time, but nevertheless, even after 21 days of storage, these differences were visible or noticeable. The carbon monoxide level used prior to vacuum packing also affected the $\Delta \mathrm{E}$ value, regardless of the storage time. Increases in the carbon monoxide concentration in the gas mixtures used for the $\mathrm{CO}$ exposure caused larger differences in the steak color. The meat from the heifers appeared more likely to be susceptible to the carbon monoxide treatment than the meat from the bulls, because it reached higher $\Delta \mathrm{E}$ values in the first two weeks of storage.

This data confirms that exposing meat to carbon monoxide before vacuum packaging allows for a visible improvement in the color in comparison to traditional vacuum packaging. In addition, we found that even the samples treated with only $0.1 \% \mathrm{CO}$ reached $\Delta \mathrm{E}$ values higher than 1.5 , which are classified as visible changes.

\subsection{Consumer assessment}

The mean scores for the consumer evaluation of the vacuum-packed steaks are shown in Table 3. There was no significant effect of animal sex on the consumer assessment ( $p>0.05$ ). Instead, the consumer evaluations depended significantly on the type of packaging and the storage time $(\mathrm{p}<0.001)$. The color of the meat packaged in a vacuum without exposure to carbon monoxide was evaluated as purple. This is because purple deoxymyoglobin is formed on the surface of meat when it is in a vacuum under anaerobic conditions, which is the main drawback of this packaging (Cornforth \& Hunt, 2008). The use of carbon monoxide significantly improved the color assessment of the vacuum-packaged meat $(\mathrm{p}<0.001)$.

Carbon monoxide causes a stable cherry-red carboxymyoglobin complex to form on the surface of meat (El-Badawi et al., 1964). The vacuum-packaged meat with the lowest $\mathrm{CO}$ exposure during the primary packaging was a purple-red, whereas those treated with $0.3 \%$ and $0.5 \%$ of carbon monoxide were red or cherry-red, respectively. The color evaluation also changed with increasing storage time $(\mathrm{p}<0.001)$, and the consumers noticed a significant deterioration of the color over time. This could indicate an increase in the share of deoxymyoglobin on the sample surface and a partial disintegration of the carboxymyoglobin during storage.

In addition, the consumers noticed a significant increase in surface discoloration (10-20\%) over time, which was greatest for the vacuum-packed meat stored for 17 and 21 days. Exposing the meat to carbon monoxide before vacuum packaging significantly prevented the discoloration of the meat surface during storage. Sen et al. (2014) reported a higher degree of discoloration $(>60 \%)$ for vacuum-packed beef after 9 days of refrigerated storage.

It is worth noting that consumers considered the steaks packaged in a vacuum to be unattractive, and they had no desire to purchase those samples (Table 3). Increasing the carbon monoxide concentration significantly improved the meat's attractiveness and the consumers' willingness to buy it. The results of our study also showed that the visual scores for these characteristics decreased significantly with increasing storage time.

Exposing meat to carbon monoxide before vacuum packaging significantly improved its consumer evaluation. Studies by Sørheim et al. (1999) also noted that meat packed using carbon

Table 3. Effect of the packaging and storage time on the consumer evaluation of longissimus dorsi muscle.

\begin{tabular}{|c|c|c|c|c|c|c|c|c|c|c|}
\hline \multirow[b]{2}{*}{$\begin{array}{c}\text { Sensory } \\
\text { parameter }\end{array}$} & \multirow{2}{*}{$\begin{array}{c}\text { Vacuum } \\
\text { packaging } \\
\text { conditions }\end{array}$} & \multirow[b]{2}{*}{7 days } & \multirow[b]{2}{*}{10 days } & \multicolumn{2}{|c|}{ Storage time } & \multirow[b]{2}{*}{21 days } & \multirow[b]{2}{*}{ SE } & \multicolumn{3}{|c|}{ Significance of effect } \\
\hline & & & & 14 days & 17 days & & & packaging & $\begin{array}{l}\text { storage } \\
\text { time }\end{array}$ & $\begin{array}{l}\text { packaging } \mathrm{x} \\
\text { storage time }\end{array}$ \\
\hline \multirow{4}{*}{ Colour } & $0 \% \mathrm{CO}$ & 4.02 & 4.15 & 4.67 & 4.93 & 5.00 & \multirow{4}{*}{$0.50-0.98$} & \multirow{4}{*}{$* * *$} & \multirow{4}{*}{$* * *$} & \multirow{4}{*}{$* * *$} \\
\hline & $0.1 \% \mathrm{CO}$ & 3.03 & 3.12 & 3.08 & 3.33 & 3.20 & & & & \\
\hline & $0.3 \% \mathrm{CO}$ & 3.10 & 2.33 & 2.80 & 2.33 & 2.90 & & & & \\
\hline & $0.5 \% \mathrm{CO}$ & 2.92 & 2.32 & 2.63 & 2.17 & 2.43 & & & & \\
\hline \multirow{4}{*}{$\begin{array}{c}\text { Surface } \\
\text { discoloration }\end{array}$} & $0 \% \mathrm{CO}$ & 1.43 & 1.55 & 1.73 & 2.38 & 2.50 & \multirow{4}{*}{$0.30-0.66$} & \multirow{4}{*}{$* * *$} & \multirow{4}{*}{$* * *$} & \multirow{4}{*}{$* * *$} \\
\hline & $0.1 \% \mathrm{CO}$ & 1.35 & 1.50 & 1.52 & 1.52 & 1.53 & & & & \\
\hline & $0.3 \% \mathrm{CO}$ & 1.32 & 1.42 & 1.80 & 1.73 & 1.55 & & & & \\
\hline & $0.5 \% \mathrm{CO}$ & 1.22 & 1.33 & 1.62 & 1.38 & 1.58 & & & & \\
\hline \multirow{4}{*}{ Attractiveness } & $0 \% \mathrm{CO}$ & 2.22 & 2.05 & 2.17 & 1.60 & 1.68 & \multirow{4}{*}{$0.71-1.08$} & \multirow{4}{*}{$* * *$} & \multirow{4}{*}{$* * *$} & \multirow{4}{*}{$* * *$} \\
\hline & $0.1 \%$ CO & 3.84 & 3.73 & 3.48 & 2.98 & 3.27 & & & & \\
\hline & $0.3 \% \mathrm{CO}$ & 4.10 & 3.97 & 3.80 & 3.85 & 3.55 & & & & \\
\hline & $0.5 \% \mathrm{CO}$ & 4.37 & 4.22 & 3.77 & 3.88 & 3.62 & & & & \\
\hline \multirow{4}{*}{$\begin{array}{l}\text { Willingness to } \\
\text { buy }\end{array}$} & $0 \% \mathrm{CO}$ & 2.12 & 2.00 & 2.07 & 1.83 & 1.53 & \multirow{4}{*}{$0.73-1.12$} & \multirow{4}{*}{$* * *$} & \multirow{4}{*}{$* * *$} & \multirow{4}{*}{$* * *$} \\
\hline & $0.1 \%$ CO & 3.82 & 3.77 & 3.50 & 2.98 & 2.99 & & & & \\
\hline & $0.3 \% \mathrm{CO}$ & 3.80 & 3.85 & 3.68 & 3.73 & 3.55 & & & & \\
\hline & $0.5 \%$ CO & 4.15 & 4.20 & 3.95 & 3.62 & 3.55 & & & & \\
\hline
\end{tabular}

$0 \% \mathrm{CO}$ - vacuum packing; $0.1 \% \mathrm{CO}$ - vacuum packing after 48 hours exposure to $0.1 \% \mathrm{CO}, 30 \% \mathrm{CO}_{2}, 69.9 \% \mathrm{~N}_{2}$; $0.3 \% \mathrm{CO}$ - vacuum packing after 48 hours exposure to $0.3 \%$ CO, $30 \% \mathrm{CO}_{2}, 69.7 \% \mathrm{~N}_{2} ; 0.5 \% \mathrm{CO}$ - vacuum packing after 48 hours exposure to $0.5 \% \mathrm{CO}, 30 \% \mathrm{CO}_{2}, 69.5 \% \mathrm{~N}_{2} ; \mathrm{XX}-$ heifer, $\mathrm{XY}-$ bull, $\mathrm{SE}-$ standard error, significant level: ${ }^{\star} \mathrm{p}<0.05$, ${ }^{* *} \mathrm{p}<0.01,{ }^{* *} \mathrm{p}<0.001 ; \mathrm{n}=15$; for color evaluation: 1 - pinkish red, 2 - bright red, 3 - cherry red, 4 - purple red/dark red, 5 - reddish tan/ reddish brown, 6 - tan/brown/gray; for surface discoloration: 1 - no visible, 2 - slight (up to 10\%), 3 - small (11-20\%), 4 - moderately (21-60\%), 5 - severe (61-100\%); for attractiveness: 1 - very unattractive, 2 - rather unattractive, 3 - moderately attractive, 4 - attractive, 5 - very attractive; for willingness to buy: 1 - definitely not buy, 2 - rather not buy, 3 - perhaps buy, 4 - buy, 5 definitely buy. 
Table 4. Pearson's correlation coefficient (r) between the physical parameters and consumer evaluation for longissimus dorsi muscle.

\begin{tabular}{|c|c|c|c|c|c|c|c|}
\hline & $\mathrm{L}^{*}$ & $\mathrm{a}^{*}$ & $\mathrm{~b}^{*}$ & $\mathrm{pH}$ & Colour & Surface discoloration & Attractivenes \\
\hline$a^{*}$ & ns & & & & & & \\
\hline$b^{*}$ & 0.47 & 0.87 & & & & & \\
\hline $\mathrm{pH}$ & -0.80 & ns & ns & & & & \\
\hline Colour & ns & -0.77 & -0.71 & ns & & & \\
\hline Surface discoloration & ns & -0.59 & ns & ns & 0.67 & & \\
\hline Attractiveness & ns & 0.83 & 0.74 & ns & -0.95 & -0.71 & \\
\hline Willingness to buy & ns & 0.84 & 0.76 & ns & -0.94 & -0.68 & 0.99 \\
\hline
\end{tabular}

ns - no significant correlation, $\mathrm{p}>0.05$.

monoxide was preferred more by consumers than meat that was vacuum packaged. Analyzing the results of the consumer assessment, it can be seen that the most attractive meat colors were bright red and cherry red. Similar meat color preferences have been shown for consumers in the Unated States and Germany (Killinger et al., 2004; Grebitus et al., 2013).

\subsection{Relationship between the instrumental parameters and consumer assessment}

The results of this experiment indicate a certain correlation between the physical parameters of the meat and the consumer evaluation scores (Table 4). For striploin muscle, there was no noticeable correlation between the brightness and the consumers' evaluations of the beef. Even though it has been claimed that the color of meat is most dependent on $\mathrm{a}^{*}$ parameter (Olivera et al., 2013; Sen et al., 2014), in our experiment a strong negative correlation was observed between the $\mathrm{a}^{*}$ and $\mathrm{b}^{*}$ values and the consumer color evaluations ( $r>0.7$ at significance level of 0.05 ). This suggests that yellowness is as important as redness in the consumer assessment. As the values of these parameters increased, the color assessment decreased, which, according to the adopted scale, means that the meat was considered more red. A strong correlation was also noted between the $\mathrm{a}^{*}$ and $\mathrm{b}^{*}$ values and the meat's attractiveness and the consumers' willingness to buy it. The consumers preferred the meat with the higher color parameter values. These results confirm that meat color significantly affects purchasing decisions, which is consistent with Carpenter et al's (2001) results. Similarly, a study by Rogers et al. (2014) found that a better color assessment was obtained for steaks packaged using $0.4 \%$ CO-MAP than for those vacuum-packaged with $80 \%$ $\mathrm{O}_{2}$-MAP. Consumers also declared their greatest purchasing intent for the steaks packaged with carbon monoxide. Many previous studies on the factors affecting consumers' assessments of pork (Ngapo et al., 2004, 2007; Fortomaris et al., 2006) have indicated that color (light and dark red were most desired) was the most important factor determining a consumer's decision to purchase pork meat.

\section{Conclusion}

The use of low carbon monoxide concentrations before vacuum packaging of beef has a positive effect and improves its color parameters. The red color of the steaks that were vacuum-packaged after prior exposure to carbon monoxide was maintained for up to 21 days of storage. Exposing the meat surface to carbon monoxide increased its attractiveness and the consumers' desire to buy vacuum-packaged meat.

The results of this study suggest that prior treatment with carbon monoxide would allow vacuum packaging to be used in retail for small portions of raw beef, making it possible to reduce the size of the packages. At the same time, it provides a considerable improvement in the color and attractiveness of the meat.

\section{Acknowledgements}

Research was performed within the Project no POIG.01.03.01-00-204/09 Optimizing of Beef Production in Poland According to "From Fork to Farm" Strategy co-financed by the European Regional Development Fund under the Innovative Economy Operational Programme 2007-2013.

\section{References}

Behrends, J. M., Mikel, W. B., Armstrong, C. L., \& Newman, M. C. (2003). Color stability of semitendinosus, semimembranosus, and biceps femoris steaks packaged in a high-oxygen modified atmosphere. Journal of Animal Science, 81(9), 2230-2238. PMid:12968698.

Carpenter, C. E., Cornforth, D. P., \& Whittier, D. (2001). Consumer preferences for beef color and packaging did not affect eating satisfaction. Meat Science, 57(4), 359-363. http://dx.doi.org/10.1016/ S0309-1740(00)00111-X. PMid:22061707.

Cayuela, J. M., Gil, M. D., Bañón, S., \& Garrido, M. D. (2004). Effect of vacuum and modified atmosphere packaging on the quality of pork loin. European Food Research and Technology, 219(4), 316-320. http://dx.doi.org/10.1007/s00217-004-0970-x.

Cornforth, D., \& Hunt, M. (2008). Low-Oxygen Packaging of Fresh Meat with Carbon Monoxide: Meat Quality, Microbiology, and Safety. AMSA, 2, 1-10.

Cserhalmi, Z. S., Sass-Kiss, Á., Tóth-Markus, M., \& Lechner, N. (2006). Study of pulsed electric field treated citrus juices. Innovative Food Science \& Emerging Technologies, 7(1-2), 49-54. http://dx.doi. org/10.1016/j.ifset.2005.07.001.

De Santos, F., Rojas, M., Lockhorn, G., \& Brewer, M. S. (2007). Effect of carbon monoxide in modified atmosphere packaging, storage time and endpoint cooking temperature on the internal color of enhanced pork. Meat Science, 77(4), 520-528. http://dx.doi.org/10.1016/j. meatsci.2007.04.031. PMid:22061937.

El-Badawi, A. A., Cain, R. F., Samuels, C. E., \& Anglemeier, A. F. (1964). Color and pigment stability of packaged refrigerated beef. Food Technology, 18, 754-757. 
European Commission - EC. Health \& Consumer Protection DirectorateGeneral. (2001). Opinion of the Scientific Committee on Food on the use of carbon monoxide as component of packaging gases in modified atmosphere packaging for fresh meat (adopted on 13 December 2001). Brussels: European Commission. Retrieved from http://ec.europa. eu/food/fs/sc/scf/out112_en.pdf

Fortomaris, P., Arsenos, G., Georgiadis, M., Banos, G., Stamataris, C., \& Zygoyiannis, D. (2006). Effect of meat appearance on consumer preferences for pork chops in Greece and Cyprus. Meat Science, 72(4), 688-696. http://dx.doi.org/10.1016/j.meatsci.2005.09.019. PMid:22061881.

Grebitus, C., Jensen, H. H., \& Roosen, J. (2013). US and German consumer preferences for ground beef Packaged under a modified atmosphere - Different regulations, different behaviour? Food Policy, 40, 109-118. http://dx.doi.org/10.1016/j.foodpol.2013.02.005.

Hunt, M. C., Mancini, R. A., Hachmeister, K. A., Kropf, D. H., Merriman, M., De Lduca, G., \& Milliken, G. (2004). Carbon monoxide in modified atmosphere packaging affects color, shelf life, and microorganisms of beef steaks and ground beef. Journal of Food Science, 69(1), FCT45FCT52. http://dx.doi.org/10.1111/j.1365-2621.2004.tb17854.x.

Hur, S. J., Jin, S. K., Park, J. H., Jung, S. W., \& Lyu, H. J. (2013). Effect of Modified Atmosphere Packaging and Vacuum Packaging on Quality Characteristics of Low Grade Beef During Cold Storage. Asian-Australasian Journal of Animal Sciences, 26(12), 1781-1789. http://dx.doi.org/10.5713/ajas.2013.13225. PMid:25049769.

Jayasingh, P., Cornforth, D. P., Carpenter, C. E., \& Whittier, D. (2001). Evaluation carbon monoxide $(\mathrm{CO})$ treatment in modified atmosphere packaging or vacuum packaging to increase color stability of fresh beef. Meat Science, 59(3), 317-324. http://dx.doi.org/10.1016/S03091740(01)00086-9. PMid:22062786.

Jeong, J. Y., \& Claus, J. R. (2010). Color stability and reversion in carbon monoxide packaged ground beef. Meat Science, 85(3), 525-530. http://dx.doi.org/10.1016/j.meatsci.2010.02.027. PMid:20416825.

Jeong, J. Y., \& Claus, J. R. (2011). Color stability of ground beef packaged in a low carbon monoxide atmosphere or vacuum. Meat Science, 87(1), 1-6. http://dx.doi.org/10.1016/j.meatsci.2010.08.004. PMid:20850226.

Kameník, J., Saláková, A., Pavlík, Z., Bořilová, G., Hulanková, R., \& Steinhauserová, I. (2014). Vacuum skin packaging and its effect on selected properties of beef and pork meat. European Food Research and Technology, 239(3), 395-402. http://dx.doi.org/10.1007/s00217014-2233-9.

Killinger, K. M., Calkins, C. R., Umberger, W. J., Feuz, D. M., \& Eskridge, K. M. (2004). Consumer visual preference and value for beef steaks differing in marbling level and color. Journal of Animal Science, 82(11), 3288-3293. PMid:15542475.

Laville, E., Sayd, T., Morzel, M., Blinet, S., Chambon, C., Lepetit, J., Renand, G., \& Hocquette, J. F. (2009). Proteome changes during meat aging in tough and tender beef suggest the importance of apoptosis and protein solubility for beef aging and tenderization. Journal of Agricultural and Food Chemistry, 57(22), 10755-10764. http://dx.doi.org/10.1021/jf901949r. PMid:19860418.

Luño, M., Roncalés, P., Djenane, D., \& Beltrán, J. A. (2000). Beef shelf life in low $\mathrm{O}_{2}$ and high $\mathrm{CO}_{2}$ atmospheres containing different low CO concentrations. Meat Science, 55(4), 413-419. http://dx.doi. org/10.1016/S0309-1740(99)00170-9. PMid:22061573.

Mancini, R. A., Suman, S. P., Konda, M. K. R., \& Ramanathan, R. (2009). Effect of carbon monoxide packaging and lactate enhancement on the color stability of beef steaks stored at $1{ }^{\circ} \mathrm{C}$ for 9 days. Meat Science, 81(1), 71-76. http://dx.doi.org/10.1016/j.meatsci.2008.06.021. PMid:22063964.
Mano, S. B., Ordóñez Pereda, J. A., \& García de Fernando, G. D. (2002). Aumento da vida útil e microbiologia da carne suína embalada em atmosfera modificada. Ciência e Tecnologia Alimentos, 22(1), 1-10. http://dx.doi.org/10.1590/S0101-20612002000100002.

Marches, C. M., Cichoski, A. J., Zanoelo, E. F., \& Dariva, C. (2006). Influência das condições de armazenamento sobre os pigmentos cárneos e a cor do salame italiano fatiado. Ciência e Tecnologia Alimentos, 26(3), 697-704. http://dx.doi.org/10.1590/S010120612006000300033.

Martínez, L., Djenane, D., Cilla, I., Beltrán, J. A., \& Roncalés, P. (2005). Effect of different concentrations of carbon dioxide and low concentration of carbon monoxide on the shelf-life of fresh pork sausages packaged in modified atmosphere. Meat Science, 71(3), 563-570. http://dx.doi.org/10.1016/j.meatsci.2005.04.041. PMid:22060934.

Mistura, L. P. F., \& Colli, C. (2009). The effect of irradiation and thermal process on beef heme iron concentration and color properties. Ciência e Tecnologia Alimentos, 29(1), 195-199. http://dx.doi.org/10.1590/ S0101-20612009000100030.

Ngapo, T. M., Martin, J. F., \& Dransfield, E. (2004). Consumer choices of pork chops: results from three panels in France. Food Quality and Preference, 15(4), 349-359. http://dx.doi.org/10.1016/S09503293(03)00082-X.

Ngapo, T. M., Martin, J. F., \& Dransfield, E. (2007). International preferences for pork appearance: I. Consumer choices. Food Quality and Preference, 18(1), 26-36. http://dx.doi.org/10.1016/j. foodqual.2005.07.001.

Olivera, D. F., Bambicha, R., Laporte, G., Cárdenas, F. C., \& Mestorino, N. (2013). Kinetics of colour and texture changes of beef during storage. Journal of Food Science and Technology, 50(4), 821-825. http://dx.doi.org/10.1007/s13197-012-0885-7. PMid:24425988.

Rogers, H. B., Brooks, J. C., Martin, J. N., Tittor, A., Miller, M. F., \& Brashears, M. M. (2014). The impact of packaging system and temperature abuse on the shelf life characteristics of ground beef. Meat Science, 97(1), 1-10. http://dx.doi.org/10.1016/j.meatsci.2013.11.020. PMid:24468705.

Sakala, R. M., Hayashidani, H., Kato, Y., Hirata, T., Makino, Y., Fukushima, A., Yamada, T., Kaneuchi, C., \& Ogawa, M. (2002). Change in the composition of the microflora on vacuum-packaged beef during chiller storage. International Journal of Food Microbiology, 74(1-2), 87-99. http://dx.doi.org/10.1016/S0168-1605(01)00732-2. PMid:11929174.

Šcetar, M., Kurek, M., \& Galic, K. (2010). Trends in meat and meat products packaging - a review. Croatian Journal of Food Science and Technology, 2(1), 32-48.

Sen, A. R., Muthukumar, M., Naveena, B. M., \& Ramanna, D. B. V. (2014). Effects on colour characteristics of buffalo meat during blooming, retail display and using vitamin $\mathrm{C}$ during refrigerated storage. Journal of Food Science and Technology, 51(11), 3515-3519. http://dx.doi.org/10.1007/s13197-012-0882-x. PMid:26396356.

Seydim, A. C., Acton, J. C., Hall, M. A., \& Dawson, P. L. (2006). Effects of packaging atmospheres on shelf-life quality of ground ostrich meat. Meat Science, 73(3), 503-510. http://dx.doi.org/10.1016/j. meatsci.2006.01.010. PMid:22062490.

Sørheim, O., Nissen, H., \& Nesbakken, T. (1999). The storage life of beef and pork packaged in an atmosphere with low carbon monoxide and high carbon dioxide. Meat Science, 52(2), 157-164. http://dx.doi. org/10.1016/S0309-1740(98)00163-6. PMid:22062367.

Suman, S. P., Mancini, R. A., Ramanathan, R., \& Konda, M. R. (2009). Effect of lactate-enhancement, modified atmosphere packaging, and muscle source on the internal cooked colour of beef steaks. Meat Science, 81(4), 664-670. http://dx.doi.org/10.1016/j.meatsci.2008.11.007. PMid:20416573. 
Troy, D. J., \& Kerry, J. P. (2010). Consumer perception and the role of science in the meat industry. Meat Science, 86(1), 214-226. http:// dx.doi.org/10.1016/j.meatsci.2010.05.009. PMid:20579814.

U.S. Food and Drug Administration - FDA. (2002). February 21, 2002 GRAS Notice No. 000083. Retrieved from http://www.fda.gov/ ForConsumers/ConsumerUpdates/ucm154596.htm

U.S. Food and Drug Administration - FDA. (2004). July 29, 2004 GRAS Notice No. 000143. Retrieved from http://www.fda.gov/ Food/IngredientsPackagingLabeling/GRAS/NoticeInventory/ ucm153974.htm
Zakrys-Waliwander, P. I., O’Sullivan, M. G., Walsh, H., Allen, P., \& Kerry, J. P. (2011). Sensory comparison of commercial low and high oxygen modified atmosphere packed sirloin beef steaks. Meat Science, 88(1), 198-202. http://dx.doi.org/10.1016/j.meatsci.2010.12.027. PMid:21237577.

Zhou, C., Tan, S., Li, J., Chu, X., \& Cai, K. (2014). A novel method to stabilize meat colour: ligand coordinating with hemin. Journal of Food Science and Technology, 51(6), 1213-1217. http://dx.doi. org/10.1007/s13197-012-0625-z. PMid:24876659. 